\section{A MANIFESTO FOR MESSY PHILOSOPHY OF TECHNOLOGY: THE HISTORY AND FUTURE OF AN ACADEMIC FIELD}

Abstract: Philosophy of technology was not initially considered a consolidated field of inquiry. However, under the influence of sociology and pragmatist philosophy, something resembling a consensus has emerged in a field previously marked by a lack of agreement amongst its practitioners. This has given the field a greater sense of structure and yielded interesting research. However, the loss of the earlier "messy" state has resulted in a limitation of the field's scope and methodology that precludes an encompassing view of the problematic issues inherent in the question of technology. It is argued that the heterodox disunity and diversity of earlier philosophy of technology was not a mark of theoretical immaturity but was necessitated by the field's complex subject matter. It is further argued that philosophy of technology should return to its pluralistic role as a meta-analytical structure linking insights from different fields of research.

Keywords: philosophy of technology; pragmatism; social construction of technology; Lewis Mumford

\section{JEAN DU TOIT}

School of Philosophy

North-West University,

Potchefstroom, South Africa

email / jean.dutoit@nwu.ac.za

(iD) 0000-0002-5297-8241

\section{Manifest pro chaotickou filosofii techniky: heistorie a budoucnost akademického oboru}

Abstrakt: Filosofie techniky nebyla zpočátku považována za ucelenou oblast bádání. Pod vlivem sociologie a pragmatické filosofie se však postupně začal utvářet určitý konsensus, který dal filosofii techniky větši strukturovanost a nová témata $k$ výzkumů. Ztráta dř́vějšiho „chaotického“ stavu však vedla k omezení rozsahu a metodiky tohoto oboru a znesnadñuje komplexní pohled, který je pro zkoumání technologie nezbytný. V tomto článku budeme zastávat pozici, že heterodoxní nejednotnost a rozmanitost dř́vější filosofie techniky nebyla známkou teoretické nezralosti, ale nutným důsledkem složitosti zkoumané oblasti. Filosofie techniky by se dle nás měla vrátit ke své pluralitní roli metaanalytické struktury, která spojuje poznatky z rüzných oblastí výzkumu.

Klíčová slova: filosofie techniky; pragmatismus; sociální konstrukce technologie; Lewis Mumford

\author{
GREGORY MORGAN SWER \\ Department of Social Sciences \\ Walter Sisulu University \\ Mthatha, Eastern Cape \\ South Africa \\ email / gregswer@gmail.com
}

iD 0000-0001-7657-2337

(c) (-) This work is licenced under the Creative Commons Attribution 4.0 International License. 


\section{Introduction}

Philosophy of technology is "one of the most recent sub-specializations in philosophy" and arose as a distinct field in philosophy only around the middle of the 20 th century. ${ }^{1}$ A lack of concern for praxis in philosophizing, a dominant focus on theoretical reasoning, and the fact that technology remained a "background phenomenon" in societies up to the twentieth century are cited as central reasons for the disregard of technology in the history of philosophy. ${ }^{2}$ However the cumulative effects of the detonation of the atomic and hydrogen bombs at Hiroshima and Nagasaki in 1945, the increasing awareness of the effects of agricultural pesticides on humans, animals, plants and ecosystems (as highlighted by Rachel Carson's Silent Spring in 1962), and the speculative implications of human cloning and genetic engineering in the 1970s, led to an increasing recognition by philosophers that technology had to be taken seriously as a subject for analysis. Technology in the contemporary era, to an unprecedented extent, forms an ever-present and deeply embedded influence in all areas of human life. Accordingly, philosophers suggested that technology not only necessitates philosophical-critical investigation, but also reconceptualisation as more than a mere extension of the natural sciences. ${ }^{3}$

This paper argues that the philosophical field that reflects on the phenomenon of technology itself demands critical self-reflection. The central focus of this paper is on the historical development of the field through two periods: the first characterized by the loose affiliation of a variety of theoretical frameworks brought to bear on the question of technology, and the latter by a shift towards pragmatic and sociological influences, and a degree of theoretical rigidity. This second period, though it has provided the field with the sense of a cohesive meta-theoretical structure, has resulted in a limitation of philosophical vision and investigative potential. In response, a return to a more holistic and pluralistic approach in the philosophy of technology

\footnotetext{
${ }^{1}$ Don Ihde, Philosophy of Technology: An Introduction (New York: Paragon House, 1993), 3.

${ }^{2}$ Ihde, Philosophy of Technology, 26; Elisabeth Ströker, "Philosophy of Technology: Problems of a Philosophical Discipline," in Boston Studies in the Philosophy of Science, vol. 80: Philosophy and Technology, eds. Paul T. Durbin and Friedrich Rapp (Dordrecht: Reidel, 1983), 323.

${ }_{3}^{3}$ J. Baird Callicott, "Non-Anthropocentric Value Theory and Environmental Ethics," American Philosophical Quarterly 21, no. 4 (1984): 299; Rachel L. Carson, Silent Spring (London: Penguin, 1962); Val Dusek, Philosophy of Technology: An Introduction (Oxford: Blackwell, 2006), 1-2; Richard Routley, "Is There a Need for a New, an Environmental, Ethic?," in Proceedings of the $X V^{\text {th }}$ World Congress of Philosophy (Varna: Sofia Press, 1973), 205.
} 
is suggested as a means of overcoming the impoverished and fragmented mode of analysis that characterises the current field.

\section{2. "Classic" Philosophy of Technology}

The philosophy of technology, as a newly established academic field, initially saw a wide variety of philosophical-critical methodologies and epistemological approaches brought to bear on the question(s) of technology. Olsen presents a succinct account of the aims of early philosophy of technology: "The philosophy of technology taken as a whole is an understanding of the consequences of technological impacts relating to the environment, the society and human existence." ${ }^{.4}$ This description provides an outline of the mandate of early developments in philosophy of technology, during which the budding field interacted strongly with a multitude of disciplines. During this initial period (from the 1930s to 1970s) a surprisingly varied influx of wide-ranging intellectual perspectives, often from historically non-communicative academic fields, were brought to bear on a topic that had up till then received little philosophical attention. Early philosophy of technology functioned to enable philosophical communication between disparate, and often apparently unrelated, branches of knowledge in analysing the phenomenon of technology.

Classic philosophy of technology analysed technology in diverse ways: at the level of artefact and system, as a form of cognition and rationality, as a metaphysical schema. It also placed emphasis on the analysis of the political and moral implications of technological development and application. ${ }^{5}$ Thus, philosophy of technology was initially not a strictly consolidated field of inquiry and involved a broad range of different fields of knowledge, such as the history and philosophy of science, psychology, ethics, feminism, politics, aesthetics and anthropology. ${ }^{6}$ Of particular note is that this lack of

${ }^{4}$ Jan K. B. Olsen, Stig A. Pedersen, and Vincent F. Hendricks, A Companion to the Philosophy of Technology (London: Blackwell Publishing, 2009), 1.

${ }^{5}$ Gregory M. Swer, "Determining Technology: Myopia and Dystopia," South African Journal of Philosophy 33, no. 2 (2014): 201-10.

${ }^{6}$ Notable participants in this initial interdisciplinary phase of technological analysis included, but was not limited to, thinkers from a variety of intellectual backgrounds such as Lewis Mumford (social science research and literary criticism), Jacques Ellul (law / theology), Langdon Winner (political science), Albert Borgmann (literary studies), Martin Heidegger (existential phenomenology), Erich Fromm (critical theory, social psychology), Herbert Marcuse (critical theory, psychoanalytic theory) and Hans Jonas (religion, phenomenology and environmental ethics). 
theoretical cohesion was not viewed as deficiency, but rather as a boon for the analysis of a phenomenon as complex and multifaceted as technology.

However, as philosophy of technology developed as a field there occurred a marked shift away from these inter-disciplinary roots. A crystallization of the field has occurred under the influence of two distinct theoretical approaches, the first derived from pragmatist philosophy and, from the 1980s onwards, from theoretical and methodological frameworks of sociological origin. This has led to a form of consensus in a field of philosophy that had been marked by a notable lack of agreement amongst its practitioners, and provided a meta-theoretical structure of sorts.

Whilst the conceptual and methodological similarities of pragmatist philosophy of technology and social constructivism will be detailed in subsequent sections, one feature shared by both approaches is their rejection of Classic philosophy of technology. For the pragmatists, Classic philosophy of technology is marked by "pessimism, utopianism, or narrowness." goes so far as to describe Classic philosophy of technology as characterised by a "state of darkness," and suggests that its "major objective seems to be to keep informed philosophical discussion of technology out of reach." ${ }^{8}$ Leading figures from this "dark" period of the field are derided for their axiological and metaphysical concerns, for their ideological bias, and for their determinist tendencies. ${ }^{9}$ Hickman describes Ellul and Heidegger as using "the technological story as a foil for [a] religious story" about the "myth of control," and Pitt writes the entire period off as "a tired old song, popular in the earlier part of this century when thinking about technology amounted to little more than indulging in an obscurantist form of metaphysics." ${ }^{10}$

Whilst the pragmatists' rejection of Classic philosophy of technology is overt, the social constructivist attitude is manifested in their general refusal to acknowledge that any variety of informed or sustained analysis of technology had occurred prior to the creation of their own field. Brey, for example, states that the types of studies described in Classic philosophy of technology "shows that certain traditional questions in the philosophy of technology are misconceived because they are based on false empirical presuppositions and

\footnotetext{
${ }^{7}$ Larry Hickman, Philosophical Tools for Technological Culture: Putting Pragmatism to Work (Bloomington: Indiana University Press, 2001), 178.

${ }^{8}$ Joseph C. Pitt, "In Search of a New Prometheus," in Broad and Narrow Interpretations of Philosophy of Technology, ed. Paul T. Durbin (Dordrecht: Kluwer, 1990), 3.

9 Hickman, Philosophical Tools, 170-71; Joseph C. Pitt, Thinking About Technology: Foundations of the Philosophy of Technology (New York: Seven Bridges Press, 2000), 87.

${ }^{10}$ Hickman, Philosophical Tools, 153; Pitt, "In Search," 3.
} 
hence need to be discarded, that other questions need to be rephrased, and that novel philosophical questions present themselves." ${ }^{11}$ The major point of contention that Brey points towards is that the theories of Classic philosophy of technology tend to be "abstract," saying "little about particular technologies and their impacts" and being less than optimal for the discussion of technology in the first place. ${ }^{12}$ Pinch and Bijker - in describing the interdependence between science and technology - suggest a fundamental misunderstanding of science and technology in Classic philosophy of technology ("they have not grasped that science and technology are themselves socially produced in a variety of social circumstances") and continue to suggest that said philosophers tend to posit overidealized distinctions (noting that "the literature on the philosophy of technology is rather disappointing"). ${ }^{13} \mathrm{Wi}$ nner suggests, however, that "Pinch and Bijker (1987) show little awareness of the literature in philosophy and technology, past or present. That does not prevent them from delivering a peremptory judgment on the matter."14

This paper does not wish to deny the important sociological and pragmatist contributions made to the field. However, it does question whether such a focus is ultimately beneficial for the continued development of the philosophy of technology, particularly in providing a theoretical toolbox from which the philosopher of technology may draw as the initial era of philosophy of technology had done. More specifically, it argues that this focus has in fact led to an impoverishment of the investigative aspects of the field, as well as to a neglect of the normative in favour of the descriptive and, increasingly, a fragmentation of research through an increased (and increasing) focus on micro-studies.

${ }^{11}$ Philip Brey, "Social Constructivism for Philosophers of Technology: A Shopper's Guide," in Readings in Philosophy of Technology, ed. Richard Kaplan (Plymouth, UK: Rowman \& Littlefield Publishers, 2009): 98-99.

${ }^{12}$ Brey, "Social Constructivism," 99.

${ }^{13}$ Trevor J. Pinch and Wiebe E. Bijker, "The Social Construction of Facts and Artifacts: Or How the Sociology of Science and the Sociology of Technology Might Benefit Each Other," Social Studies of Science 14, no. 3 (1984): 403; Trevor J. Pinch and Wiebe E. Bijker, "The Social Construction of Facts and Artifacts: Or How the Sociology of Science and the Sociology of Technology Might Benefit Each Other," in The Social Construction of Technological Systems: New Directions in the Sociology and History of Technology, eds. Wiebe E. Bijker, Thomas P. Hughes, and Trevor Pinch (Cambridge, MA: MIT Press, 1987), 13.

${ }^{14}$ Langdon Winner, "Upon Opening the Black Box and Finding it Empty: Social Constructivism and the Philosophy of Technology," Science, Technology and Human Values 18, no. 3 (1993): 377. 


\section{The Approaches and Theoretical Framework of Contemporary Philosophy of Technology}

Elisabeth Ströker, writing just as the sociological perspective was gaining traction in philosophy of technology, presents an illuminating explication of how a focus on technology solely from the sociological or pragmatic frameworks may delimit the investigative potential of philosophy of technology when she reflects on the central question of the identity and subject matter of the field. ${ }^{15}$ She describes how a shift in focus to delimited investigative frameworks has occurred in other fields before, and offers as an example the way in which the concept of "nature" in Philosophy of Nature transformed from its original conception to such an extent that only scientifically investigated nature could be explored as the field developed. Thus changing the field into a philosophy of science that could no longer conduct its philosophical investigations in the same way that the Philosophy of Nature had originally. ${ }^{16}$ Ströker then asks whether philosophy of technology, from the 1980 s onwards, was moving in a direction that rendered it incapable of investigating technology qua technology (technology as broader phenomenon) in anything other than its most scientific forms, thus becoming exclusively a philosophy of the technical sciences. In the next section it is argued that the continuing influence of sociology and pragmatism on the field has had exactly such an effect, and that the field is in danger of becoming nothing more than a philosophy of the technical sciences.

\subsection{Sociology}

Social constructivist studies rose to prominence in philosophy of technology in the mid-eighties. Social constructivists view technological problems as part of the sociology of knowledge, arguing in line with the broader social constructivism framework that claims to scientific knowledge have sociological explanations. ${ }^{17}$ Social constructivists see a continuation of science and technology, denying the possibility of their separation, and bring the analytical sociological approaches directed at science to bear on questions of technology. ${ }^{18}$ The sociological approach in philosophy of technology is

\footnotetext{
${ }^{15}$ Ströker, "Philosophy of Technology," 326.

${ }^{16}$ Ibid.

${ }^{17}$ Similarly, any broader conception of "the world" is both unnecessary and undesirable in this view. Brey, "Social Constructivism," 100.

${ }^{18}$ Pinch and Bijker, "Social Construction," 399-400.
} 
derived from the Strong Programme in the Sociology of Knowledge in the Philosophy of Science (SSK, which claims that scientific facts and objects are socially constructed). Many prominent researchers utilizing this approach in fact started out in science studies and only later turned to the investigation of technology. ${ }^{19}$ In this view, technology is always a socio-cultural artefact created via an instrumental mode of artefact production - a point perhaps less contentious than social construction of nature or physical reality because artefacts are indeed produced by humans within a particular socio-cultural context..$^{20}$ However, in this approach, we argue, there is a reduction of the technological to a form of social epistemology which focusses on knowledge creation in social environments, with the view that this knowledge production is typically, though tacitly, advantageous, useful, or an accomplishment. ${ }^{21}$ The inherent focus on the sociology of knowledge in investigating technology will often prevent a researcher from making claims about the essential nature of the phenomenon of technology. ${ }^{22}$ In other words, such a researcher will have much to say about how knowledge of technology is socially and culturally derived, but would consider any discussion of what technology specifically entails, beyond socio-cultural knowledge considerations, to be beyond the scope of inquiry and to be rather unimportant.

Social Construction of Technology (SCOT) presents the following central aspects: (1) interpretative flexibility, whereby the meaning of any technological artefact is deemed fluid and malleable in a manner that is fully dependent on shifting social relations (primarily between producer and consumer), and (2) design flexibility, whereby the design of a technological artefact is held to be open-ended and realisable in a multitude of different ways (in that the effective functioning of a technological artefact

${ }_{19}$ David Bloor, Knowledge and Social Imagery (London: Routledge and Kegan Paul, 1976); Steve Woolgar, "The Turn to Technology in Social Studies of Science," Science, Technology \& Human Values 16, no. 1 (1991): 20-50.

${ }^{20}$ Pinch and Bijker contend however, that "there is widespread agreement that scientific knowledge can be, and indeed has been, shown to be thoroughly socially constituted." Pinch and Bijker, "Social Construction," 401.

${ }^{21}$ Wiebe E. Bijker, "Technology, Social Construction of," in The International Encyclopedia of Communication, ed. Wolfgang Donsbach (Oxford: Blackwell, 2008): 5031.

${ }^{22}$ Such tabooed topics include the "(in)operativity of artifacts, technological (in)efficiency, success or failure in technical change, the (ir)rationality of technological choices and procedures, technological progress, the real function or purpose of an artifact, and intrinsic effects of technology." Brey, "Social Constructivism," 101. 
is dependent on specific social arrangements). ${ }^{23}$ Wiebe E. Bijker and Trevor J. Pinch, two key proponents of the SCOT perspective, in arguing for the superiority of their approach with regard to Classic models, have claimed that the philosophy of technology was in need of "more realistic models of both science and technology." 24 These "realistic models" are equated with empirical studies which are purported to aid the field "in arriving at analyses that are more concrete and detailed, and that are empirically more realistic" by "supporting or rejecting empirical claims made or presupposed by theories in the philosophy of technology, such as claims about technological change and technological innovation, the way technology impacts society, and the characteristics of different types of technology, and by suggesting alternative empirical claims." ${ }^{25}$ The central idea is therefore that empirical results are needed to corroborate, amend and reject theories that have an empirical component, such as theories of technology (and that such empirical results are especially needed in "social and political philosophy of technology and technology ethics, because such studies typically presuppose some empirical model of technology dynamics"). ${ }^{26}$ This turn towards the empirical in investigating technology entails an increasing focus on micro-studies of particular artefacts in particular socio-cultural contexts. ${ }^{27}$

Philip Brey highlights that such sociological studies present micro-elaborations on prominent theories of technology, especially those developed during the 1950s (what this article will refer to as Classic philosophy of technology), after the so-called empirical turn in the field of philosophy of technology. The main difficulty that we identify with such an approach is that these micro-studies do not take into account the broader tapestry of technology theorizing or a broader phenomenon of technology, instead merely presenting fragments of philosophizing on technology that do not connect to central questions regarding the character of technology. Our criticism of this position will be discussed in detail in section 4 .

\footnotetext{
${ }^{23}$ Pinch and Bijker, "Social Construction," 411, 419.

${ }^{24}$ Pinch and Bijker, Social Construction, 13.

${ }^{25}$ Brey, "Social Construction," 99.

${ }^{26}$ Ibid., 99.

${ }^{27}$ Bijker emphasizes this point by describing how the "agenda of demonstrating the social construction of artifacts by detailed analysis at the micro level [has] resulted in a wealth of case studies.” Bijker, “Technology,” 5032.
} 


\subsection{Pragmatism}

The pragmatist perspective in the philosophy of technology frames technology as a product of knowledge production processes with the goal of fulfilling a specific "useful" function. The pragmatist strand is strongly influenced by positivism and this approach is directed towards analysing particular technologies. Ihde notes that in contemporary philosophy of technology this tendency towards specificity has replaced those of the earlier Classic views by focusing centrally on the "salient, determinate, convergent tendencies" of technology. ${ }^{28}$ The pragmatist approach is founded upon three central tenets: (1) an opposition to foundationalism and the cognitive powers claimed thereby; (2) that theories of reality and the rationalistic methods that underlie such theories must be sufficiently grounded in said reality to ensure continued human survival; and (3) that the cognitive success of philosophical inquiry be continuous with and based upon the conditions of social praxis. ${ }^{29}$ The key tenets of pragmatism with regard to technology are therefore based in an instrumentalism that is directed towards "solving problems" in a specific society and in order to develop democratic societies (thus, a focus on "utility") and a value reductionism wherein the "utility" of a technological artefact is the only normative criteria for technology evaluation. This therefore implies not just an instrumentalism, but a pragmatic instrumentalism.

The pragmatic approach towards technology is exemplified in the works of Larry A. Hickman and Joe Pitt. Hickman gives a reinterpretation of John Dewey's pragmatism with regard to technology in John Dewey's Pragmatic Technology (1990), and also suggests a reformulated framework from which to approach technology - a Deweyian framework. ${ }^{30}$ All problem solving in the Deweyian framework is technological. Dewey writes, “Technology' signifies all the intelligent techniques by which the energies of nature and man are directed and used in satisfaction of human needs; it cannot be limited to a few outer and comparatively mechanical forms." ${ }^{31}$ Hickman builds on

\footnotetext{
${ }^{28}$ Don Ihde, "Has the Philosophy of Technology Arrived? A State-of-the-Art Review," The Philosophy of Science Association 71, no. 1 (2004): 123; Joseph Margolis, "Pragmatism, Transcendental Arguments, and the Technological," in Boston Studies in the Philosophy of Science, vol. 80: Philosophy and Technology, eds. Paul T. Durbin and Friedrich Rapp (Dordrecht: Reidel, 1983), 299.

${ }^{29}$ Margolis, "Pragmatism," 299-300.

${ }^{30}$ See also Hickman, Philosophical Tools for Technological Culture.

${ }^{31}$ John Dewey, The Collected Works of John Dewey, 1882-1953: The Later Works, ed. Jo Ann Boydston (Carbondale: Southern Illinois University Press, 2008), 5.270.
} 
this Deweyian stance to develop a pragmatic definition of technology that is based on "invention, development, and cognitive deployment of tools and other artifacts, brought to bear on raw materials and intermediate stock parts, with a view to the resolution of perceived problems." ${ }^{32}$ He stresses that artifacts (which he terms "tools") have no fixed essence, an important theoretical assumption in productive pragmatism, when he says that in technological description one should "put an end to speaking of tools [...] as having complete essences that predetermine and provide the measure of our ways of involvement with them. I suggest that we instead speak of the ways in which [tools] can and do serve to enhance delight and to resolve problems, that is, to enlarge the meanings of our experiences." ${ }^{33}$

Don Ihde argues that John Dewey's instrumentalism does not portray technology negatively (in putative contrast to most Classic philosophers of technology's supposedly dystopian attitude towards technology), but rather as useful. ${ }^{34}$ In fact, both Dewey and Hickman claim that pragmatic inquiry into questions of technology provides a means to solve societal problems, leading in turn to the development of democratic societies, because philosophical investigations into technology in this mode are more "empirical" and allow particular technologies to be analysed. ${ }^{35}$ In this context the "usefulness" or efficiency of the tools studied indicates ways in which one might develop "better" (i.e., "more effective") societies. Joe Pitt, who follows the same anti-essentialist line as Hickman in his pragmatist philosophy of technology, also argues against the broader analysis of technology through ethical and political perspectives. He argues that, "tools and technical systems are inherently ideologically neutral. Individuals with particular axes to grind may employ a tool to achieve their ends, but this does not make the tool itself ideological." ${ }^{36}$ On his account technology plays the practical role of developing societies that are democratic in a "non-political" fashion, i.e., it

\footnotetext{
${ }^{32}$ Hickman, Philosophical Tools, 12.

${ }^{33}$ Hickman, Philosophical Tools, 122; Eric Mullis, "The Device Paradigm: A Consideration for a Deweyan Philosophy of Technology," The Journal of Speculative Philosophy 23, no. 2 (2009): 116. Consider also Hickman's description of pragmatic deliberation as involving "tools and artifacts, whether those tools and artifacts be abstract or concrete, tangible or intangible, should be viewed as instrumental: in other words, as a form of technology." Larry Hickman, "John Dewey as a Philosopher of Technology," in Readings in the Philosophy of Technology, ed. Richard Kaplan (Plymouth, UK: Rowman \& Littlefield Publishers, 2009): 43-44.

${ }^{34}$ Ihde, "Has the Philosophy of Technology Arrived?," 123.

${ }^{35}$ Mullis, "Device Paradigm," 115.

${ }^{36}$ Pitt, Thinking, 72.
} 
leads to democratic societies because these types of societies are linked with pragmatism, and thus work.

\section{Critique of Socio-Pragmatic Philosophy of Technology (What Has Been Lost)}

Against the accounts discussed in the previous section which advocated for sociological and pragmatic positions, we argue that the loss of the fruitful, "messy" state of earlier philosophy of technology has resulted in a recategorization of the field's scope and methodology that prevents a holistic view of the problematic inherent in technological issues. In effect, the narrowing of the field has resulted in a narrowing of philosophical vision. Ströker argues that we should ask not only whether the analytical procedures utilized in modern philosophy of technology have been correctly applied, but also if "philosophical procedures, traditionally proved satisfactory, [...] no longer have 'bite." 37

In SCOT the phenomenon of technology has been reduced to an artefactual focus, attributable to a large extent to the prominent instrumentalism that is fundamental to this approach. Technology is not to be approached systemically or collectively but piecemeal, individual artefact by individual artefact. And each artefact, furthermore, is to be historically and socially isolated from the process of its development. This focus on technological innovation, Langdon Winner argues, leads to a lack of emphasis of the social consequences of technical choice, and when social consequences are acknowledged there is generally a focus on those who construct technologies rather than the social groups that are affected (suppressed or excluded) in these processes. Winner argues that the social constructivist approach has "little to say about the deep-seated political biases that can underlie the spectrum of choices that surface for relevant social actors" or the "the structural relationships between classes are fundamental conditions that underlie all economic institutions, government policies, and technological choices." ${ }^{38}$ Furthermore, the evaluative aspects that were foremost in Classic philosophy of technology are considered unimportant, as are ethical or political aspects of technology. All technological development and change is reduced to the activities of specific social groups, with no exploration of

\footnotetext{
${ }^{37}$ Ströker, "Philosophy of Technology," 325.

${ }^{38}$ Winner, "Upon Opening," 370.
} 
deeper intellectual or cultural dynamics that have a role in technology and technological development.

The narrowing of perspective that has resulted from the influence of the SCOT perspective has been furthered by the recent upsurge of interest in pragmatist philosophy. Kristin Shrader-Frechette's critique of the pragmatic approach towards technology echoes the above critique of SCOT in many areas. Attacking pragmatist philosophy of technology, especially as utilized by Pitt, she highlights the value neutralism that forms an integral part of this view, its assertion that all technologies must be considered as neutral, its belief that ethical and political analyses of technology are not needed in technological studies as these systems are self-correcting, and charges that it is uncritical towards the increasingly prominent and unregulated role of technological experts in societal decision-making. ${ }^{39,40}$ She argues that for all its vaunted empiricism and neutrality the pragmatist approach functions in an ideological manner, being "value-relative, positivist, autocratic, technocratic, and supportive of laissez-faire technological development." ${ }^{\prime 11}$ We argue that the ascendance of such an approach would curtail possible future contributions to the field. She describes the main difficulty as follows: "If one does not point out the ethical, political and democratic flaws that have led to technological disasters, then it is certain that there will be more such catastrophes. Pitt's ideological stance seems likely to have the effect of sanctioning the status quo, accepting laissez-faire technology, and accepting the opinions of experts, regardless of their errors or vested interests." ${ }^{\text {"2 }}$

We argue that value relativism, possibly ideologically applied, and the positing of the intrinsic neutrality of all technology without necessary theoretical grounding are extremely problematic credos for a mature philosophy of technology. ${ }^{43}$ These however are the difficulties that result when one

${ }^{39}$ Kristin Shrader-Frechette, "Reductionist Philosophy of Technology: Stones Thrown from inside a Glass House," Techné: Research in Philosophy and Technology 5, no. 1 (1994): 24-25.

${ }^{40}$ This suggests that the reductionist approach to the investigation of technological phenomena that typifies SCOT is also shared by the pragmatist approach.

${ }^{41}$ Schrader-Frechette, "Reductionist Philosophy of Technology," 22.

${ }^{42}$ Ibid., 27. Schrader-Frechette's critique here of Pitt's pragmatism does call to mind the Frankfurt School's critique of the value-neutrality of positivism.

${ }^{43}$ Furthermore, one may question these approaches' preferred method of analysis: the microstudy. Brey queries the usefulness of micro-studies for broader evaluative studies of technology, such as "empirical studies of impacts of technology and of initial settings of the agenda and the exclusion of social groups in technological innovation, or for "deeper" social and cultural factors that play a role in technological development," due to the narrow focus and lack of broader scope of such studies. Brey, "Social Criticism," 103. We are forced to express scepticism 
defines technology solely as a knowledge production process. And this in turn points to our central issue with the current socio-pragmatic consensus, namely that it fails to address the primary question that has motivated philosophy of technology from the outset: What is the nature of technology and what does technology mean?

In this regard, the main difficulty with both of these approaches may be summarized as follows:

1. Both approaches favour micro-studies over macro-level analyses. Whilst useful for developing empirical accounts of specific technological instances, there can be no foundational theorizing on technology itself. Philosophical vision and investigative capability are thereby reduced as each of these micro-studies present only a fragmentary sketch of the phenomenon of technology and do not aim towards a greater coherent account of technology. Such a focus also disregards systematic elaborations in the field.

2. Value relativism becomes an argumentative basis, which leads to the divorcing of the descriptive from the normative. This implies that technology is neutral, and any further investigation into aspects beyond this central point is deemed superfluous.

3. All of philosophy of technology is reduced to a social epistemology, i.e., the analysis of technology understood solely as a process of knowledge creation within a particular social environment, while all other areas of philosophical inquiry are abandoned (these topics include the moral, metaphysical, political, aesthetic, and ontological). Such a reduction of the field allows no multi-disciplinary investigation to occur.

Whilst we concede that SCOT (as sociology) has a place as part of the integrative framework of the philosophy of technology, we maintain that it does not per se have the necessary theoretical grounding to serve successfully as the framework for investigations in philosophy of technology. To an extent pragmatism may contribute to such a role, but in contrast to SCOT there is some difficulty with integrating pragmatism with other integrative approaches towards philosophy of technology.

concerning the possibility that the progressive accumulation of "empirical" micro-studies divorced from a wider interpretative theoretical framework could ever yield information of any great philosophical significance. Indeed, it calls to mind Darwin's criticism of induction, that one might as well sit in the gravel pit and count the pebbles. 
In short, while not hostile towards the contributions from these disciplines we do want to highlight the flaws of such approaches. Moreover, a singular focus on either sociology or pragmatism leads to an impoverishment of the investigative aspects of the field and increasingly a fragmentation of the field. Furthermore, we argue that the philosophy of technology represents a philosophical field where one does not particularly want a rigid interpretative structure and resultant limitation of the investigative capabilities of the field to happen. Rather, what is needed in the field is an expanded, integrative approach that can successfully bridge a variety of analytic approaches. There is an increasing sense that the fruitful, almost messy state that was initially present in the field has been lost and that the recategorization of technology that has occurred in the field of late does not present a complete view of the problematic inherent in technological issues. If the Classic phase of the philosophy of technology shows us one thing it is that the phenomenon of technology is often concealed in social systems to such an extent that a variety of investigative approaches are required to trace it. It is also characterised by a continual development and reshaping that sociological and pragmatic studies often cannot trace due to an inability or unwillingness to investigate technology qua technology. ${ }^{44}$

\section{Looking Backwards: A Case Study in Classic Philosophy of Technology}

We argue that the heterodox disunity of earlier philosophy of technology was not a mark of its theoretical immaturity, but was necessitated by the nature of the field's subject matter, and that the philosophy of technology should return to its original pluralistic and messy role as a meta-analytical structure linking insights from different fields of research and bringing them to bear on technological matters. A clear proponent of such an approach is Lewis Mumford, whose investigation into the mechanical clock typifies how tracing a technological instance from a multi-disciplinary approach opens up new investigative horizons and provides us with new insights into the phenomenon of technology.

Mumford describes the clock in Technics and Civilization (1934) as "the most influential of machines, mechanically as well as socially; and by the

\footnotetext{
${ }^{44}$ In other words, one cannot grasp technology as it presents itself in all its complexity if one commits in advance to the position that technology is, in essence, just another process of knowledge production.
} 
middle of the eighteenth century it had become the most perfect: indeed, its inception and its perfection pretty well delimit the eotechnic phase." ${ }^{\prime 45}$ The way in which Mumford analyses the origin and development of the mechanical clock in Technics and Civilization exemplifies the multi-disciplinary nature of Classic philosophy of technology. His account draws upon a variety of fields, including theology, psychology, sociology, economics, architecture, Lebensphilosophie (13), the history of science and technology (14), science (natural) and mathematics (15), history (general) (16), astronomy (17), philosophy (18), art and cartography (19), literature (19), semiotics (20). This description shows the broad sweep with which Mumford approaches questions of technology. It is important to note that all the elements that Mumford draws from these fields are not simply listed but woven into an integrative theoretical framework.

Such an approach is necessary, on Mumford's account, as no individual artefact can be understood in isolation from its social milieu. Mumford states, "the machine cannot be divorced from its larger social pattern; for it is this pattern that gives it meaning and purpose." ${ }^{36}$ Whilst he does not reject the view that technology may have a profound influence on the form and nature of society, Mumford asserts that the development of a technological ideology is the main cause of both the existence of technological forms and the ability of those forms to shape society. Each technological phase is not to be understood as a definite and bounded historical period, but a cultural tendency taking both ideological, aesthetic and artefactual forms. Given this view the only way to comprehend a technological microcosm is to grasp it in relation to a wider cultural macrocosm. And the only way to do this is to draw upon the research of all relevant academic fields, and to employ the full spectrum of philosophical analysis, from the aesthetic to the ethical.

Central to Mumford's position is the view that for all its hostility to previous forms of holistic existence, modern technology constantly creates the means and potential for the construction of new ones. ${ }^{47}$ Whilst he views the

\footnotetext{
${ }^{45}$ Lewis Mumford, Technics and Civilization (London: Routledge \& Kegan Paul, 1934), 134. Mumford suggests that we understand the technological history of Western society as consisting of three phases: the eotechnic, paleotechnic and the neotechnic. Mumford characterises these phases by reference to the forms of material and the forms of energy that were predominant within them. Thus, the eotechnic represents a water and wood complex, the paleotechnic a coal and iron complex and the neotechnic an electricity and alloy complex.

${ }^{46}$ Ibid., 110.

${ }^{47}$ This runs contrary to the current tendency to dismiss Classic philosophy of technology as "dystopian," "pessimistic," or even "anti-technological."
} 
development of modern technics and the rise of modern capitalism to be closely connected, he does not hold that modern technics is intrinsically hostile to other, non-capitalist, forms of society. And whilst he also acknowledges the power of technical forms to create, dissolve and alter social relations and ideological forms, he does not hold that the latter are determined by the former. Mumford categorically rejects the technicist Marxist position that the technological mode of production creates the dominant ideologies of the period, which in turn serves to justify those relations of production already in existence. Such a view amounts to the assertion that ideological forms are essentially epiphenomenal with regard to the social organisation of a technological culture. Instead Mumford argues that it is the ideological that has primacy over the technological. The mechanical ideology was both historically and necessarily prior to the development of modern technics. "Men had become mechanical before they perfected complicated machines to express their new bent and interest." ${ }^{\text {"48 }}$ Thus, to truly understand the genesis of even an individual technological artefact, one must be cognisant of wider cultural currents. Social epistemology alone will not be able to capture, to return to Mumford's example of the clock, the way this "new attitude toward time and space infected the workshop and the counting house, the army and the city." ${ }^{\prime 2}$ The workshop cannot be the entirety of the story of technology.

The purpose of this brief retrospective is not to argue for the truth of Mumford's philosophy of technology nor for its revival. ${ }^{50}$ Rather we wish to endorse its ambition, its awareness of the sheer scope of the technological phenomenon, its recognition of the necessity for an integrative theoretical framework, and the aspiration to provide at least the outlines of the latter. ${ }^{51}$ We would further argue that there are good reasons to believe that the conceptual conditions that initially gave rise to the field of the philosophy of technology (reflected in the rapid development of new digital technologies with the potential to cause both harm and good) are re-emerging and need to be investigated by contemporary philosophy of technology, and necessi-

\footnotetext{
${ }^{48}$ Ibid., 3.

${ }^{49}$ Ibid., 20.

${ }^{50}$ However, this is not to suggest that the approaches put forward in Classic philosophy of technology do not remain relevant to the analysis of contemporary technology. See for instance Jean du Toit, "Between Thanatos and Eros: Erich Fromm and the Psychoanalysis of Social Networking Technology Use," South African Journal of Philosophy 38, no. 2 (2019): 136-48.

${ }^{51}$ Even if one has no sympathy for Mumford's prioritising of the ideological, one can at least admire his attention to the dialectical process between social and technological in his analysis of the conceptual framework (rigorous temporal structuring in the rhythms of monastic life) that preceded the clock.
} 
tates the use of a variety of intellectual frameworks and the development of a more versatile, fully-formed academic field.

We turn from the clock to a more contemporary example that we feel indicates the complexity of current technological phenomenon: the selfie. Discussion on the nature and meaning of the selfie involve subjects such as bodily dysmorphia, the technological reproduction of the image, the aesthetics of self-perception, gender and sexual objectification, cultural dynamics, clinical narcissism, virtual immortality, post-technological ethics, to name but a few. Consider briefly the whole range of different specialist fields involved in even this most cursory overview of the topic. The selfie represents the type of multi-faceted technological problematic that the impoverished socio-pragmatic approach does not and indeed could not accommodate.

To describe the selfie adequately, we argue, calls for a loose integrative framework capable of synthesising the insights of a host of different disciplines, including but not limited to the sociological, and bringing to bear all modes of philosophical analysis, including but not limited to the social epistemological.

\section{Conclusion (Manifesto)}

Elizabeth Ströker ends her 1983 investigation into the problems of the field of philosophy of technology, after surmising that a more definite structure is needed in the field, by asking: "Could it be [...] that philosophy of technology sets too much store by greater systematization?" ${ }^{2}$ In this article we have attempted to show how such a definite structure, through a focus on sociology and pragmatism in modern philosophy of technology, leads to an investigative impoverishment in the field. We would answer her final question in the affirmative, suggesting that a return to the lack of systematization that was initially present in the field is called for.

Early philosophy of technology was not a strictly consolidated field of inquiry. Technology was seen as involving the interaction of a variety of different fields of knowledge such as philosophy of science, ethics, political philosophy, aesthetics, philosophy of religion and anthropology ${ }^{53}$ Each of these fields relates and integrates with technological issues in some fundamental ways. The multi-disciplinary character of the field was clearly reflected in the 1960s heyday of Classic philosophy of technology which communicated

\footnotetext{
${ }^{52}$ Ströker, "Philosophy of Technology," 334.

${ }^{53}$ Dusek, Philosophy of Technology, 2.
} 
with often compartmentalized, competing or non-communicating branches of philosophy, such as political philosophy and philosophy of science, allowing a combination and synthesis of these fields. It is necessary to emphasize furthermore that these fields were seen as not only related, but rather interdependent with regards to views on technology.

Crucially, the newly-developed academic field served a unifying function in its investigation of technology. The reason for this seems clear: Technology as subject matter for a philosophical discipline is exceptionally difficult to pin down, and in some cases the phenomenon of technology does not reveal itself to analysis immediately. ${ }^{54}$ Technology has moved beyond the water wheel and ox cart to become enmeshed with humanity and the ways in which humanity lives. When one settles for either a "technical" (Technik) or "technological sciences" (Technologie) account, the broader description of the subject matter in philosophy of technology becomes muddled, and even more so the intertwined and dialectical relationship between the human and the technological. The same occurs when only the pragmatist and sociological perspectives are allowed to dominate the theoretical approaches utilized in the field. Both these perspectives suffer from a profound confusion of the concepts of theory and praxis, often formulated (especially in pragmatism) as opposites. In technology such a distinction is problematic, as the theory and the praxis of technology are intertwined in an idiosyncratic way that differentiates the field from the natural sciences, for example.

Ströker suggests, in line with our argument in this article, that the philosophy of technology "may have peculiarities of its own that go beyond the specific subjects and methods which by tradition constitute a philosophical discipline." ${ }^{55}$ These characteristics do not have correlates in the subject matter of other philosophical disciplines due to the "paradox" of the field's "continual beginning." ${ }^{6}$ The nature of technology thus suggests that a multi-disciplinary, "messy," approach may suit philosophy of technology as an academic field best.

Ihde also highlights the fundamental difference between philosophy of science and philosophy of technology, not just in how these two fields originated but also with regards to the "problems sets" or subject matter with which they deal. He states that "philosophies of science, philosophies of technology and science studies are all in degree necessarily interdisciplinary

\footnotetext{
${ }^{54}$ If, as Marcuse argued, technology has become second nature, then nature still loves to hide.

${ }^{55}$ Ströker, "Philosophy of Technology," 323.

${ }^{56}$ Ibid., 323.
} 
in practice and location," but the specific character of technology requires that the boundaries of the field of philosophy of technology should be less rigid and vigorously defended than the borders of philosophy and science studies. ${ }^{57}$

The "messy" approach that we therefore suggest is not meant to imply incoherence; rather our argument is the opposite. What is needed is a coherent account and analysis of technology (based on investigating not just the "what" but also the "why") that importantly allow the incorporation of a breadth of methodological approaches due to the multi-faceted subject matter that philosophy of technology investigates. Different investigative approaches may therefore be brought to bear on questions of technology that appear to be the same and would not lead to contradiction, but rather philosophical reconciliation, in the field.

Thus, in philosophy of technology there should be a return to the traditional role of the field which allowed an integrated, meta-analytical analysis of technology through an acknowledgement that the field of research is not structurally homogenous. The attempt to develop a structure in philosophy of technology that is analogous to philosophy of science or philosophy of art is fundamentally flawed due to the peculiar characteristics of the field's subject matter, detailed in the preceding sections. It is our belief that only an acknowledgement of these characteristics can lead to philosophizing on technology that is truly capable of encompassing its complex and protean nature.

\section{Bibliography:}

Bijker, Wiebe E. “Technology, Social Construction of." In The International Encyclopedia of Communication, edited by Wolfgang Donsbach, 5031-36. Oxford: Blackwell, 2008. https://doi.org/10.1002/9781405186407.wbiect025.

Bloor, David. Knowledge and Social Imagery. London: Routledge and Kegan Paul, 1976.

Brey, Philip. "Social Constructivism for Philosophers of Technology: A Shopper's Guide." In Readings in Philosophy of Technology, edited by Richard Kaplan, 98-112. Plymouth, UK: Rowm an \& Littlefield Publishers, 2009.

${ }^{57}$ Ihde, "Has the Philosophy of Technology Arrived?," 124. 
Brey, Philip. "Philosophy of Technology after the Empirical Turn.” Techné: Research in Philosophy and Technology 14, no. 1 (2010): 36-48.

https://doi.org/10.5840/techne20101416.

Carson, Rachel L. Silent Spring. London: Penguin, 1962.

Callicott, J. Baird. "Non-Anthropocentric Value Theory and Environmental Ethics.” American Philosophical Quarterly 21, no. 4 (1984): 299-309.

Dewey, John. The Collected Works of John Dewey, 1882-1953: The Later Works, edited by Jo Ann Boydston. Carbondale: Southern Illinois University Press, 2008.

Dusek, Val. Philosophy of Technology: An Introduction. Oxford: Blackwell, 2006.

Hickman, Larry. John Dewey's Pragmatic Technology. Bloomington: Indiana University Press, 1990.

Du Toit, Jean. "Between Thanatos and Eros: Erich Fromm and the Psychoanalysis of Social Networking Technology Use.” South African Journal of Philosophy 38, no. 2 (2019): 136-48. https://doi.org/10.1080/02580136.2019.1630543.

Hickman, Larry. Philosophical Tools for Technological Culture: Putting Pragmatism to Work. Bloomington: Indiana University Press, 2001.

Hickman, Larry. "John Dewey as a Philosopher of Technology." In Readings in the Philosophy of Technology, edited by Richard Kaplan, 43-55. Plymouth, UK: Rowman \& Littlefield Publishers, 2009.

Ihde, Don. Philosophy of Technology: An Introduction. New York: Paragon House, 1993. https://doi.org/10.1086/381417.

Ihde, Don. "Has the Philosophy of Technology Arrived? A State-of-the-Art Review." The Philosophy of Science Association 71, no. 1 (2004): 117-31.

Margolis, Joseph. "Pragmatism, Transcendental Arguments, and the Technological." In Boston Studies in the Philosophy of Science, vol. 80: Philosophy and Technology, edited by Paul T. Durbin and Friedrich Rapp, 291-312. Dordrecht: Reidel, 1983. https://doi.org/10.1007/978-94-009-7124-0_20.

Mitcham, Carl. "Notes Towards a Philosophy of Meta-Technology." Society for Philosophy and Technology 1, no. 1-2 (1995): 13-17.

https://doi.org/10.5840/techne199511/25.

Mullis, Eric. "The Device Paradigm: A Consideration for a Deweyan Philosophy of Technology." The Journal of Speculative Philosophy 23, no. 2 (2009): 110-17. 
Mumford, Lewis. Technics and Civilization. London: Routledge \& Kegan Paul, 1934.

Olsen, Jan K. B., Stig A. Pedersen, and Vincent F. Hendricks. A Companion to the Philosophy of Technology. London: Blackwell Publishing, 2009. https://doi.org/10.1002/9781444310795.

Pinch, Trevor J., and Wiebe E. Bijker. "The Social Construction of Facts and Artifacts: Or How the Sociology of Science and the Sociology of Technology Might Benefit Each Other." Social Studies of Science 14, no. 3 (1984): 399-441. https://doi.org/10.1177/030631284014003004.

Pinch, Trevor J., and Wiebe E. Bijker. "The Social Construction of Facts and Artifacts: Or How the Sociology of Science and the Sociology of Technology Might Benefit Each Other." In The Social Construction of Technological Systems: New Directions in the Sociology and History of Technology, edited by Wiebe E. Bijker, Thomas P. Hughes, and Trevor J. Pinch, 11-44. London: MIT Press, 1987.

Pitt, Joseph C. "In Search of a New Prometheus." In Broad and Narrow Interpretations of Philosophy of Technology, edited by Paul T. Durbin, 3-16. Dordrecht: Kluwer, 1990. https://doi.org/10.1007/978-94-009-0557-3_1.

Pitt, Joseph C. Thinking About Technology: Foundations of the Philosophy of Technology. New York: Seven Bridges Press, 2000.

Pitt, Joseph C. Doing Philosophy of Technology: Essays in a Pragmatist Spirit. London: Springer, 2011.

Shrader-Frechette, Kristin. "Reductionist Philosophy of Technology: Stones Thrown from inside a Glass House." Techné: Research in Philosophy and Technology 5, no. 1 (1994): 21-28. https://doi.org/10.5840/techne20015115.

Ströker, Elisabeth. "Philosophy of Technology: Problems of a Philosophical Discipline." In Boston Studies in the Philosophy of Science, vol. 80: Philosophy and Technology, edited by Paul T. Durbin and Friedrich Rapp, 323-36. Dordrecht: Reidel, 1983. https://doi.org/10.1007/978-94-009-7124-0_23.

Swer, Gregory M. "Determining Technology: Myopia and Dystopia." South African Journal of Philosophy 33, no. 2 (2014): 201-10. https://doi.org/10.1080/02580136.2014.923696.

Routley, Richard. "Is There a Need for a New, an Environmental, Ethic?" In Proceedings of the XVth World Congress of Philosophy. 205-10. Varna: Sofia Press, 1973. https://doi.org/10.5840/wcp151973136. 
Winner, Langdon. "Upon Opening the Black Box and Finding it Empty: Social Constructivism and the Philosophy of Technology." Science, Technology and Human Values 18, no. 3 (1993): 362-78.

https://doi.org/10.1177/016224399301800306.

Woolgar, Steve. "The Turn to Technology in Social Studies of Science." Science, Technology \& Human Values 16, no. 1 (1991): 20-50.

https://doi.org/10.1177/016224399101600102. 